\title{
Strategi Eksklusi pada Film Dokumenter The Mahuzes Karya Watchdoc Documentary: Kajian Critical Discourse Analysis Theo Van Leeuwen
}

\author{
Irma Suryani*, Kamiyatein, Julisah Izar \\ Universitas Jambi, Indonesia \\ Gedung G, FKIP Jalan Raya Jambi Muara Bulian KM 15 Mendalo Indah \\ *Correspondence email: irmauryai@uja.ac.id, kamiyateingma36a@gmail.com, julisahizar@unja.ac.id
}

\begin{abstract}
Abstrak. Penelitian ini bertujuan untuk mengkaji konstruksi strategi eksklusi yang digunakan oleh Watchdoc dalam film dokumenterThe Mahuzes. Data yang digunakan dalam penelitian ini adalah teks tuturan dalam film yang diperoleh dari hasil transkripsi. Metode yang digunakan adalah metode deskriptif kualitatif dengan menggunakan kajian Critical Discourse Analysis pendekatan Van Leeuwen. Hasil penelitian menunjukkan bahwa Watchdoc menggunakan strategi pasivasi dan nominalisasi dalam menghilangkan aktor sosial di dalam film melalui narasi deskripsi, tuturan wartawan, dan keterangan dari masyarakat adat. Watchdoc menggunakan bentuk pasivasi dijadikan, dibongkar, dibersihkan dan nominalisasi perebutan, penggusuran, dan pembongkaran untuk mengkritisi kebijakan pemerintah dan kegiatan industri perusahaan di Papua. Dengan menghilangkan sosok aktor di dalam film, penonton akan berpikir kritis mengenai oknum yang terlibat dalam peristiwa dan keadaan yang merugikan masyarakat adat di Papua.
\end{abstract}

Kata kunci: eksklusi; pasivasi; nominalisasi; masyarakat adat.

Abstract. This study aims to examine the construction of the exclusion strategy used by Watchdoc in The Mahuzes documenter film. The data used in this research is the text of the speech in the film obtained from the transcripts.The method used is a descriptive qualitative method with Van Leeuwen approach to Critical Discourse Analysis (CDA). The result showed that Watchdoc used passivation and nominalization strategies to eliminating social actors in the film trough narrative descriptions, journalists speech, and adat community stories. Watchdoc uses the form of passivation dijadikan, dibongkar, dibersihkan and nominalization perebutan, penggusuran, andpembongkaran to criticize government policies and corporate industrial activities in Papua. By eliminating the actors in the film, the audience will think critically about the people involved in events and circumstances that are destrimental to adat community in Papua.

Keywords: exclusion; passivation; nominalization; adat community.

\section{PENDAHULUAN}

Dalam kehidupan sehari-hari, manusia menggunakan berbagai alat komunikasi sebagai perantara untuk menyampaikan pesan atau informasi. Salah satu sarana komunikasi yang digunakan untuk menyebarkan informasi atau pesan kepada khalayak umum adalah media massa. Informasi yang terdapat pada media massa biasanya memuat nilai-nilai sosial dengan tujuan tertentu. Hal ini sejalan dengan peran atau fungsi media massa dalam kehidupan masyarakat, yakni sebagai alat untuk menyebarkan nilai-nilai kepada khalayak umum. Peran tersebut akan mempengaruhi norma yang ada dan ideologi media pun mempengaruhi nilai-nilai yang berkembang di tengah masyarakat. Beberapa bentuk media massa yang paling umum ditemui dalam kehidupan sehari-hari yaitu koran, media massa elektronik, dan film.

Sebagai salah satu media komunikasi massa, film memiliki peran penting dalam mengkonstruksi sebuah realitas yang ada dalam kehidupan masyarakat. Selain digunakan untuk sarana hiburan, film dapat menyampaikan pesan-pesan yang merepresentasikan keadaan atau ideologi tertentu menggunakan bahasa di dalam film.Hal ini sejalan dengan pendapat (Sosiowati, 2013) yang menyatakan bahwa penggunaan bahasa dapat menyampaikan ideologi tertentu kepada pendengarnya.Dengan menggunakan tampilan audio visual, pesan-pesan yang ingin disampaikan melalui filmlebih menarik untuk dilihat oleh penonton.Hingga saat ini, terdapat dua bentuk film yang telah dikenal oleh masyarakat, yaitu film teatrikal dan non-teatrikal (Mudjiono, 2011).Film teatrikal bersifat dramatis dan lebih menonjolkan fungsi hiburan. Sementara film nonteatrikal adalah film yang biasanya digunakan sebagai alat komunikasi massa dan sebagai media edukasi. Salah satu bentuk film non-teatrikal adalah film dokumenter.

Film dokumenter berkaitan dengan jurnalistik karena kerap menggunakan metode liputan yang menyesuaikan dengan realita di lapangan. Hal tersebut yang membedakan film dokumenter dengan jenis film lainnya. Dengan menggunakan media audio visual, realita yang digambarkan oleh film dokumenter dianggap sebagai liputan faktual yang menggambarkan keadaan atau fenomena tertentu di masyarakat. Karena liputan film dokumenter minim rekayasa, maka produksinya pun dilakukan tanpa naskah dialog seperti 
film dramatik. Biasanya pihak produksi akan mewawancarai pihak-pihak tertentu yang menjadi sorotan film sehingga penonton dapat memperoleh gambaran langsung dari konten yang disajikan. Salah satu rumah produksi film dokumenter di Indonesia yakni Watchdoc Documentary.

Watchdoc adalah salah satu production house yang telah dikenal oleh masyarakat Indonesia sebagai pembuat film dokumenter dengan tema sosial.Karya Watchdoc yang ditampilkan dalam tajuk Ekspedisi Indonesia Biru merupakan karya fenomenal yang mengundang berbagai kontroversi.Hal ini disebabkan karena keseluruhan konten dari Ekspedisi Indonesia Biru adalah liputan keliling Indonesia yang menyoroti keadaan masyarakat Indonesia dengan kompleksitas masalahnya.Tidak hanya sekedar memberi informasi kepada penonton, Watchdoc juga menghadirkan wacanawacana tertentu pada setiap series liputan.Selain itu Watchdoc juga kerap menghasilkan film dokumenter dengan mengambil sudut pandang masyarakat adat dengan pemikirannya yang menjadi perhatian di dalam film. Hal ini terlihat pada liputan Ekspedisi Indonesia Biru yang mengambil sudut pandang masyarakat Samin dalam film berjudul Samin VS Semen, masyarakat Baduy dalam film Baduy, masyarakat adat Mentawai dalam film Made in Siberut, masyarakat adat Boti dalam film Boti, dan masyarakat Malind dalam film The Mahuzes.

Film The Mahuzes menjadi bagian dalam Ekspedisi Indonesia Biru yang menyoroti perjuangan orang Malind dalam mempertahankan tanahnya melawan perusahaan kelapa sawit dan proyek MIFEE (Muharromah, 2019). Watchdoc mengambil sudut pandang suku Malind dan marga Mahuze yang menolak alih fungsi lahan dan memperjuangkan hak tanah adatnya.Secara tidak langsung, Watchdoc mengkritik kebijakan pemerintah dalam proyek food estate yang mengancam identitas masyarakat adat di Merauke.Melalui film The Mahuzes, penonton disuguhi dengan wacana konflik antara masyarakat adat yang tinggal di wilayah konsesi dengan perusahaan yang telah mendapat izin dari pihak terkait. Dalam film tersebut Watchdoc menggunakan beberapa cara untuk merepresentasikan permasalahan atau wacana yang terjadi, diantaranya yakni dengan menggunakan kalimat atau deskripsi tertentu.

Wacana yang terdapat pada film The Mahuzes dapat dikaji dengan menggunakan pendekatan Critical Discourse Analysis (CDA). Dalam kajian analisis wacana kritis, teks yang ditampilkan kepada khalayak umum tidak bersifat bebas karena terdapat faktor sosial masyarakat dan produksi teks yang mempengaruhinya (Fauzan, 2014).CDA memiliki beberapa pendekatan untuk mengkaji konstruksi sebuah wacana yang dipengaruhi dan mempengaruhi konteks sosial masyarakat (Mills, 1995).Salah satu pendekatan dalam CDA yang digunakan untuk mengkaji bagaimana suatu kelompok sosial menempati posisi sebagai kelompok yang dimarginalkan yakni dengan menggunakan pendekatan Theo Van Leeuwen (Aksara., 2001).

Dalam pendekatan Van Leeuwen, gambaran mengenai sebuah peristiwa dan aktor tertentu yang dimarginalkan pada sebuah teks dapat dilihat dari kehadirannya di dalam wacana yang ditampilkan. Pendekatan ini melihat bagaimana aktor sosial direpresentasikan dan diwujudkan secara linguistik oleh sebuah media (Van Leeuwen, 2008). Terdapat dua kategori representasi menurut (Van Leeuwen, 2008), yaitu inklusi dan eksklusi. Dalam ranah inklusi, aktor sosial dihadirkan dalam wacana. Sementara pada eksklusi, aktor sosial dihilangkan dengan tujuan tertentu.Penelitian ini bertujuan untuk mengkaji konstruksi eksklusi yang meliputi pasivasi dan nominalisasi dalam film The Mahuzes dan mendeskripsikan maksud dari strategi tersebut.

\section{METODE}

Metode yang digunakan dalam penelitian ini adalah metode kualitatif deskriptif.Penelitian yang bersifat kualitatif merupakan metode penelitian yang memecahkan masalah dengan mendeskripsikan objek penelitian (Moleong, 2000).Peneliti menggunakan Critical Discourse Analysis (CDA) atau Analisis Wacana Kritis pendekatan Theo Van Leeuwen (Van Dijk, 1985) dengan kajian eksklusi yang membongkar konstruksi aktor sosial yang termaginalkan di dalam wacana.

Sumber data dalam penelitian ini adalah teks tuturan dalam film The Mahuzes yang dipublikasikan di akun YouTube Watchdoc Image pada tanggal 29 Agustus 2015. Teks tersebut diperoleh peneliti dari hasil transkripsi tuturan masyarakat di dalam film.Data pada penelitian ini dibatasi hanya pada data berupa bentuk pasivasi dan nominalisasi di dalam teks yang menunjukkan adanya gambaran eksklusi. Peneliti menggunakan teknik simak dan transkripsi pada film The Mahuzes. Peneliti melakukan pengamatan pada objek penelitian dan mengumpulkan data sekunder dengan metode library research.Menurut (Hadi, 1986) library research merupakan metode yang digunakan untuk mengumpulkan sumber referensi yang relevan dengan penelitian.

\section{HASIL DAN PEMBAHASAN}

Berdasarkan analisis data yang telah dilakukan, terlihat bahwa pihak produksi film (Watchdoc) memihak masyarakat adat yang menjadi sorotan di dalam film.Strategi pasivasi dan nominalisasi yang digunakan pada narasi deskripsi film dan tuturan wartawan bertujuan untuk tidak melibatkan kelompok atau aktor sosial tertentu di dalam wacana. Deskripsi dan tuturan tersebut berfungsi untuk menggambarkan peristiwa di 
lapangan sehingga penonton meletakkan perhatian pada keadaan masyarakat adat di Papua.Hasil penelitian tersebut dapat dideskripsikan dalam pembahasan sebagai berikut. Terdapat dua bentuk eksklusi yang digunakan oleh Watchdoc di dalam film The Mahuzes, yakni pasivasi dan nominalisasi. Data pasivasi di dalam film ditemukan pada deskripsi dan tuturan wartawan. Sementara nominalisasi ditemukan pada tuturan masyarakat adat.

\section{Pasivasi}

Pasivasi adalah proses penghilangan aktor di dalam teks (Aksara., 2001) Melalui pasivasi, korban akan lebih disorot karena aktor atau pelaku tidak berada di dalam teks. Proses tersebut secara tidak langsung akan menarik perhatian khalayak umum pada peristiwa apa yang terjadi, bukan pada aktor yang menyebabkan peristiwa tersebut terjadi. Data berupa pasivasi ditemukan dalam narasi deskripsi yang dihadirkan Watchdoc di scene awal film dan tuturan masyarakat adat yang menjadi sorotan.Penghilangan aktor melalui pasivasi ini digunakan oleh Watchdoc untuk menonjolkan peristiwa yang terjadi pada masyarakat adat sebagai korban dari kegiatan industri perusahaan sehingga penonton lebih fokus untuk mengetahui isi informasi dari sisi masyarakat adat.Strategi pasivasi dalam film The Mahuzes terlihat pada data berikut:

(1) Papua hendak dijadikan lumbung pangan dan energi dunia berbasis perusahaan (industry). Proyek ini disebut Merauke Integrated Food and Energy Estate (MIFEE).

Bentuk pasif pada data (1) menghilangkan sosok yang ingin menjadikan Papua sebagai lumbung pangan dan energi melalui proyek MIFEE.Jika merujuk pada proses proyek tersebut, MIFEE adalah mega proyek yang dicanangkan oleh pemerintah pada masa kepemimpinan presiden Susilo Bambang Yudhoyono pada tahun 2010. Namun, proyek tersebut tidak kunjung direalisasikan hingga akhirnya dicanangkan kembali pada tahun 2015 di masa pemerintahan presiden Joko Widodo. Adanya usulan untuk menjadikan Papua sebagai lokasi proyek dinilai bertentangan dengan keadaan sosial masyarakat setempat yang notabene merupakan masyarakat adat. Melalui penggunaan pasivasi tersebut, pemahaman makna konten pun akan sejalandengan paradigma yang dimiliki oleh penonton. Jika penonton adalah khalayak yang pro dengan proyek MIFEE, maka pemaknaan terhadap narasi tersebut adalah pemaknaan yang memihak kepada kebijakan pemerintah. Namun jika penonton film adalah pihak yang kontra dengan proyek MIFEE, maka pemaknaannya pun akan sebaliknya dan mengkritisi kebijakan tersebut.

Dengan penggunaan verba pasifdijadikan, fokus dalam narasi tersebut lebih kepada subjek kalimat,
yaitu'Papua' yang menjadi lokasi proyek. Jika aktor sosial ditampilkan dalam narasi tersebut, maka penonton akan menyoroti sosok aktor yang berperan menjadikan Papua sebagai target lokasi proyek. Namun hal ini menunjukkan bahwa pihak produksi film ingin lebih menyoroti pihak masyarakat adat di Papua.Hal ini dibuktikan dengan alur film yang lebih mengarah pada pandangan masyarakat adat mengenai proyek tersebut sehingga Watchdoc menggunakan strategi pasivasi pada data (1) untuk membuat pihak masyarakat adat di Papua mendapat sorotan publik.

\section{(2) sudah berapa hektar hutan yang dibongkar Pak?}

Pada data (2) di atas terdapat bentuk pasivasi 'dibongkar'.Kalimat pada data (2) adalah pertanyaan yang diajukan oleh wartawan kepada masyarakat Malind saat scene menyusuri Kali Bian.Pada pertanyaan tersebut, pihak media tidak menyebutkan siapa sosok yang membongkar hutan atau membuka lahan di wilayah tersebut. Hal ini justru menunjukkan bahwa media sebenarnya telah mengetahui siapa yang berperan dalam pembukaan lahan tersebut. Strategi pasivasi pada pertanyaan tersebut membuat mitra tutur menjawab secara general mengenai jumlah hutan yang telah dibongkar. Jika pihak media mempertanyakan luas hutan yang telah dibongkar oleh perusahaan tertentu, maka penonton akan lebih menyoroti perusahaan tersebut.

Padahal terdapat beberapa perusahaan yang beroperasi di sekitar tempat tinggal masyarakat adat dan telah menimbulkan beberapa kerugian. Misalnya perusahaan SIS di Zanegi, perusahaan Dongin Prabhawa di Distrik Ngguti, perusahaan Rajawali Group di Domande, dan perusahaan lainnya di hulu Kali Bian yang telah membongkar hutan (Konflik Agraria Masyarakat Hukum Adat Atas Wilayahnya di Kawasan Hutan, 2016).Sebagian dari wilayah pembongkaran umumnya merupakan wilayah penting masyarakat adat yang meliputi tanah adat, dusun sagu, wilayah mata pencaharian, dan wilayah keramat masyarakat.

Namun pihak Watchdoc tidak menghadirkan aktor yang melakukan pembongkaran tersebut dengan tujuan agar penonton lebih meletakkan perhatian kepada dampak negatif dari pembongkaran hutan kepada masyarakat adat. Jika aktor yang membongkar hutan dihadirkan dalam wacana, maka pihak media harus melakukan wawancara dan meliput pandangan dari pihak tersebut. Hal ini akan menyebabkan kompleksitas masalah yang dihadirkan oleh film The Mahuzes bertambah besar sehingga tidak fokus lagi kepada masyarakat Malind. Maka strategi pasivasi tersebut digunakan untuk mendapatkan fokus liputan sesuai perencanaan.

(3) Wartawan : tapi belum dibersihkan? 
Darius : belum, jadi baru mulai digusur itu. Gara-gara kemarin kami dikasih suap itu, itu nanti begitu terus sampai kesini. Nah, yang ini hutan ini, itu sudah masuk dalam arealnya. Itu nanti digusur semuanya.

Pada data (3) terdapat bentuk pasivasi 'dibersihkan'. Pertanyaan tersebut diajukan oleh wartawan setelah mengetahui bahwa air Kali yang menjadi tempat masyarakat minum dan mencari ikan tidak bisa digunakan sebagaimana biasanya setelah ada perusahaan kelapa sawit yang beroperasi di sekitar kali. Strategi pasivasi pada pertanyaan tersebut akan membuat penonton beranggapan bahwa pencemaran lingkungan di sekitar tempat tinggal warga berdampak cukup signifikan terhadap kehidupan sehari-hari mereka. Pemikiran ini akan membuat penonton mempertanyakan siapa pihak dibalik pencemaran tersebut.

Strategi pasivasi pada data di atas digunakan oleh Watchdoc sebagai upaya untuk menggambarkan keadaan lingkungan masyarakat adat. Dengan penghilangan aktor tersebut, khalayak umum akan mengetahui bahwa kegiatan industri kelapa sawit di sekitar Kali Bian menyebabkan kerugian bagi masyarakat setempat. Kerugian ini meliputi kurangnya akses masyarakat terhadap hutan adat, tercemarnya lingkungan tempat masyarakat mencari sumber makanan, dan berkurangnya ekosistem di hutan tempat masyarakat berburu. Upaya pasivasi tersebut akan menggiring pandangan khalayak umum bahwa tentu proyek yang lebih besar akan menyebabkan dampak yang lebih besar pula dari segi lingkungan dan sosial. Meskipun strategi pasivasi bersifat menghilangkan aktor dalam wacana yang dihadirkan, namun strategi tersebut juga akan mempengaruhi cara pandang publik terhadap pihak terkait yang berhubungan langsung dengan masyarakat yang menjadi sorotan film.

\section{Nominalisasi}

Nominalisasi adalah pengubahan verba menjadi nomina (Aksara., 2001). Proses nominalisasi dilakukan untuk menghilangkan aktor tertentu dalam wacana dan umumnya dilakukan dengan menambahkan imbuhan pean (Aksara., 2001). Nominalisasi dapat menghilangkan aktor di dalam teks karena tidak membutuhkan subjek di dalam kalimat. Hal ini disebabkan karena nominalisasi adalah proses mengubah bentuk verba atau tindakan ke bentuk nomina atau peristiwa. Bentuk verba atau tindakan dalam kalimat membutuhkan subjek atau pelaku, sementara nomina tidak membutuhkan pelaku karena mendeskripsikan mengenai peristiwa. Misalnya bentukverbamembunuh diubah menjadi nominapembunuhan. Pada verba membunuh membutuhkan keterangan mengenai siapa yang melakukan tindakan, sementara nomina pembunuhan tidak menerangkan mengenai aktor yang melakukan tindakan pembunuhan karena hanya memberi informasi kepada khalayak bahwa telah terjadi pembunuhan.

Dalam film The Mahuzes, terdapat beberapa bentuk nominalisasi yang digunakan oleh penutur di dalam film. Tuturan tersebut tidak sepenuhnya bertujuan untuk menghilangkan pelaku melainkan digunakan agar khalayak umum mengetahui peristiwa yang terjadi di lapangan. Strategi nominalisasi pada film The Mahuzes dapat diuraikan sebagai berikut.

(1) Kisah ini tentang orang-orang MALIND DEQ yang mempertahankan tanah menghadapi kelapa sawit. Dengan kisah perebutan tanah $200.000 \mathrm{Ha}$ ini, kita punya gambaran bagaimana dengan 1,2 juta Ha.

Pada data (1) di atas terdapat bentuk nominalisasi 'perebutan' yang terdapat pada narasi pembuka film. Pihak media menggunakan bentuk nomina perebutan untuk menghilangkan sosok aktor sosial yang berperan dalam peristiwa perebutan tanah adat. Namun dalam hal ini Watchdoc tidak bermaksud untuk membela aktor yang dihilangkan pada narasi tersebut melainkan ingin menggambarkan kepada khalayak umum bahwa terjadi pengalihan hak tanah milik masyarakat Malind dengan cara yang tidak sewajarnya. Pada narasi pembuka film ini, Watchdoc mendeskripsikan bahwa orang Malind adalah kelompok masyarakat adat yang menentang alih fungsi lahan agar Sumber Daya Alam yang mereka miliki tetap terjaga. Namun, proyek industri yang menargetkan Merauke sebagai wilayah konsesi mulai mengancam kelestarian alam dan tanah adat yang selama ini digunakan sebagai sumber kehidupan oleh warga setempat.

Sejalan dengan hal tersebut, perusahaan yang akan membuka lahan di wilayah konsesi harus berhadapan dengan masyarakat adat sebagai pemilik dari tanah ulayat. Sewajarnya ada kesepakatan yang terjalin antara kedua belah pihak mengenai hak tanah. Namun masyarakat adat sering dihadapkan pada persoalan kesepakatan dan informasi yang kurang jelas dari pihak perusahaan sehingga menyebabkan potensi munculnya konflik antara masyarakat setempat dengan perusahaan. Pada narasi di atas pihak Watchdoc tidak menyebutkan aktor atau pihak yang merebut tanah milik masyarakat Malind. Penggunaan nominalisasi perebutan bertujuan agar penonton lebih fokus kepada keadaan yang dialami oleh masyarakat adat dan akibat dari perebutan tanah tersebut.

(2) Tapi sekarang karena banyak perusahaan dan penggusuran akhirnya sekarang kami jadi begini. Sudah tidak bisa lihat ikan lagi di permukaan air.

Pada data (2) terdapat bentuk nominalisasi yang dituturkan dalam pernyataan Darius Nenob (kepala 
suku) kepada pihak Watchdoc. Penutur bermaksud untuk menggambarkan keadaan Kali Bian yang sudah tercemar setelah adanya perusahaan yang masuk dan beroperasi di wilayah mereka. Perbandingan paling mendasar mengenai keadaan air kali adalah tingkat kejernihan air yang menurun. Saat wilayah tempat tinggal dan hutan adat belum masuk dalam area konsesi, masyarakat adat bisa dengan mudah mencari ikan dan meminum air kali langsung dari sumbernya karena kejernihan dan kualitas air yang dinilai baik. Namun hal sebaliknya terjadi ketika perusahaan mulai beroperasi di sekitar Kali Bian. Air yang semula jernih menjadi kecoklatan sehingga menyebabkan masyarakat setempat kesulitan untuk mencari ikan san mendapatkan sumber air bersih. Untuk menggambarkan keadaan tersebut, penutur menggunakan nominalisasi 'penggusuran'.

Kata penggusuran pada nominalisasi data di atas berasal dari bentuk verba menggusur. Berdasarkan hal tersebut, dapat diketahui bahwa ada sosok di balik penggusuran. Namun, penutur tidak menyebutkan secara detail mengenai pihak yang telah menggusur hutan adat milik masyarakat Malind. Dalam hal ini penonton dapat mengansumsikan bahwa yang menggusur hutan adat adalah perusahaan yang telah mendapatkan izin untuk mengelola lahan. Namun karena tidak jelas siapa yang ada dibalik penggusuran tersebut, penonton menjadi tidak kritis dan lebih memfokuskan perhatian pada kondisi kali yang tercemar.

(3) Itu siapa yang membawa kau pergi ke sana? Pembongkaran ini setelah kamu pertemuan. Kamu dalam rangka apa? Itu tanah sudah berpalang, kenapa kamu sibuk? Kau jujur. Tidak usah berputar-putar. Saya tahu kau itu bagaimana. Terbuka, saya minta satu itu,buka. Jangan kau tipu. Tanah itu bukan milik kamu pribadi. Semua punya hak.

Tuturan pada data (3) mengandung strategi nominalisasi 'pembongkaran'. Pada kalimat tersebut, penutur bermaksud untuk mendeskripsikan bahwa peristiwa pembongkaran atau penebangan hutan yang terjadi di wilayah tanah adat adalah peristiwa yang serius dan harus diusut hingga tuntas. Hal ini dikarenakan persoalan tanah adat dianggap sebagai permasalahan bersama yang melibatkan seluruh anggota marga. Oleh sebab itu tidak diperkenankan bagi masyarakat adat untuk menandatangani kesepakatan pengalihan hak tanah atas nama pribadi. Nominalisasi pembongkaran digunakan oleh penutur untuk mendeskripsikan kejadian yang terjadi pada tanah adat marga Mahuze.

Pada data tuturan tersebut, penutur sebagai masyarakat adat marga Mahuze merasa ada kejanggalan dalam proses pembukaan lahan di tanah adat milik mereka. Pasalnya, marga Mahuze merasa tidak pernah bersepakat dengan pihak perusahaan dalam pengalihan hak tanah. Masyarakat adat mencurigai adanya perbuatan curang dari oknum-oknum tertentu dalam peristiwa ini. Oleh sebab itu dalam rapat marga besar yang dilakukan pasca adanya pembongkaran, masyarakat adat berusaha keras untuk menemukan solusi dari permasalahan tersebut. Bentuk nominalisasi pembongkaran membuat khalayak umum fokus memperhatikan kondisi lingkungan dan sistem kepemilikan tanah adat yang sakral pada masyarakat Mahuze. Deskripsi yang dilakukan oleh masyarakat adat melalui tuturannya akan menciptakan persepsi bahwa tanah adat merupakan hal yang berharga bagi masyarakat setempat.

\section{SIMPULAN}

Berdasarkan hasil analisis dan pembahasan mengenai strategi eksklusi dalam film The Mahuzes dengan menggunakan kajian analisis wacana kritis pendekatan Van Leeuwen ini, dapat ditarik kesimpulan bahwa Watchdoc Documentary sebagai pihak produksi film memihak masyarakat adat Papua. Pada umumnya strategi eksklusi yang digunakan oleh media bersifat memihak aktor yang dihilangkan. Namun, dalam film The Mahuzes meskipun eksklusi bersifat menghilangkan aktor sosial, strategi tersebut bertujuan agar peristiwa yang terjadi di lapangan tergambar dengan jelas. Hal ini akan mempengaruhi pemaknaan penonton terhadap isi film dokumenter yang disajikan.

Strategi eksklusi di dalam film The Mahuzes dilakukan dengan menggunakan dua cara, yakni melalui pasivasi dan nominalisasi. Pasivasi terdapat pada narasi deskripsi awal film dan tuturan wartawan. Dengan menggunakan pasivasi berupa dijadikan, dibongkar, dan dibersihkan, pihak Watchdoc bermaksud untuk mengkritisi pemerintah dan perusahaan yang berperan dalam mengelola kegiatan industri di wilayah konsesi. Sebagai pihak yang berwenang menerapkan kebijakan, pemerintah justru memarginalkan posisi masyarakat adat Papua dengan mencanangkan mega proyek pangan dan energi. Sementara perusahaan digambarkan sebagai pihak yang tidak bertanggung jawab karena menyebabkan ekosistem menjadi tercemar sehingga menimbulkan kerugian bagi masyarakat adat.

Sedangkan nominalisasi dalam film tersebut terdapat pada tuturan masyarakat adat yang menjelaskan keadaan dan peristiwa yang terjadi di sekitar lingkungan mereka dengan menggunakan kata perebutan, penggusuran, dan pembongkaran. Sama halnya seperti strategi pasivasi, bentuk nominalisasi pada film The Mahuzes juga bertujuan untuk mengkritisi pemerintah dan perusahaan. Sebagai penduduk asli Papua, masyarakat adat setempat ingin dihargai hak ulayat dan kedudukannya. Namun seringkali saat ada proyek industri baru, masyarakat adat tidak memperoleh informasi yang jelas sehingga berpotensi memunculkan konflik baru di kemudian hari. Sementara perusahaan sebagai pihak yang bekerja sama dengan pemerintah dalam usaha mendapatkan izin pengelolaan tanah juga 
kerap melakukan upaya yang merugikan masyarakat, seperti membuka lahan di tanah adat tanpa izin marga dan melakukan kegiatan industri yang membatasi aksesmasyarakat terhadap hutan adat.

Penggunaan strategi-strategi tersebut menunjukkan bahwa melalui film The Mahuzes, Watchdoc berusaha mengkritisi kebijakan pemerintah dan perusahaan di Papua. Dengan menghilangkan sosok aktor di dalam teks, pihak Watchdoc membuat khalayak umum berpikir kritis mengenai peristiwa dan keadaan yang terjadi di Papua beserta oknum-oknum yang ada di balik peristiwa tersebut.

\section{DAFTAR PUSTAKA}

Aksara., E. (2001). Analisis wacana: Pengantar analisis teks media. Yogyakart: LKiS Pelangi.

Fauzan, U. (2014). Analisis wacana kritis dari model Fairclough hingga Mill. Jurnal Pendidik , 6 (1).

Hadi, S. (1986). Metodologi Research: Untuk penulisan paper, skripsi, thesis dan disertasi. Yogyakarta: Yayasan Penerbitan Fakultas Psikologi UGM.

Komnas HAM Indonesia, (2016). Konflik Agraria Masyarakat Hukum Adat Atas Wilayahnya di Kawasan Hutan. Jakarta: Komnas HAM Republik Indonesia.

Mills, S. (1995). Feminist stylistics. London \& New Yor: Routledge.

Moleong, L. (2000). Metodologi penelitian kualitati. Bandung: PT. Remaja Rosdakarya.

Mudjiono, Y. (2011). Kajian Semiotika dalam film. Jurnal Ilmu Komunikasi , 125-138.

Muharromah. (2019). Konflik Agraria Suku Marind Orang Mahuze dan Kebijakan Pemerintah Indonesia. Jakarta: Skripsi. Universitas Islam Negeri Syarif Hidayatullah.

Sosiowati, I. G. (2013). Kesantunan Bahasa Politisi dalam Talk Show di Metro TV. Denpasa: Disertasi. Universitas Udayana.

Van Dijk, T. A. (1985). Semantic discourse analysis. Handbook of discourse analysis.

Van Leeuwen, T. (2008). Discourse and practice: New tools for critical discourse analysis. Oxford University: Oxford University Press. 